\title{
TOBACCO SMOKE AND SOME ISSUES OF PASSIVE SMOKER INTOXICATION
}

\author{
Parulava G., Doctor of Biological Sciences, Professor, Georgian State Teaching University of \\ Physical Education and Sport, Tbilisi, Georgia; \\ Gelenava N., Doctor of Biology, Associate Professor, Shota Meskhia Zugdidi State Teaching \\ University, Zugdidi, Georgia;
}

\section{DOI: https://doi.org/10.31435/rsglobal_conf/30052021/7577}

Abstract. The concentrations of nicotine, benz-a-pyrene and naphthalene in cigarette smoke in lit cigarettes were investigated after two, six and ten minutes at a distance of 2,0; 4,0 and 10,0 meters. Qualitative and quantitative analysis of smoke was performed by method of capillary gas-liquid chromatography. Data were processed using the statistical program SPSS-17. It has been established that the structure of tobacco smoke and the concentrations of nicotine, benz-a-pyrene and naphthalene change with the distance from the lit cigarette. Their ability to migrate is heterogeneous. The intensity of nicotine movement is much higher than that of benz-a-pyrene and nicotine. Thus, based on our research (migration speed, distance) it is possible to assess the risk of air pollution with tobacco smoke products. Thus, the study of air pollution issues with cigarette smoke in a closed space is an important task of human health.

Keywords: Closed space, toxic components, source of contamination, passive smoker, smoke.

Introduction. According to the literature, a tobacco smoke has more than 280 toxic components (5). Among them, nicotine content is $22-28 \%$, rest of them are "accompanying substances", which, according to their origin, are divided into two groups: 1 . Nornicotines, their toxicity is 100 times higher than of nicotine; Anabazines - also more toxic than Nicotine; Anatabine, Methylanatabine, Methylanabazine and etc. (4). 2. "Foreign genus compounds" that appear as a result of the burning of mulberry and cigarette paper pistons. The Photochemical and pyrolytic processes, during the so called puff, result in the formation of certain classes of substances in tobacco smoke. From a medical-biological point of view, particularly interesting is the class of carboxylic acids and anhydrides, where the total number of components exceeds 240 units. (A) Toxic components of tobacco smoke are primarily accumulated in the lungs and cause life-threatening, irreversible changes (1). In this regard, it is particularly important to determine the concentration of cigarette combustion products and to determine the nature of their individual migration. This topic is known as the "passive smoker" problem. The World Health Organization (WHO) reports that $52-58 \%$ of the population is a tobacco smoker (6).

The aim of the study is to determine the relationship of concentration of nicotine, benzo-apyrene and naphthalene in the cigarette smoke in closed space regarding the distance and time between lit cigarettes, when samples will be taken from the $1 \mathrm{~m}^{3}$ of air at distance of 2,0;4,0 and 10,0 meters from the source of contamination after 2,0;6,0 and 10,0 minutes from the start of the experiment.

Research results. The investigations were performed on a gas-liquid chromatograph (PPF-1, Waters), equipped with allurination and spectrophotometric detectors. Cigarettes (Astra, Georgia) were placed in a smoking machine (ГОСТ-3308), smoking parameters (ГOCT-HEO-6565), spot sampling (ГОСТ-P-50021). A total of 6 series have been conducted. Data were processed by statistical program SPSS-17.

Table 1. Levels of nicotine, nenzo-a-pyrene and naphthalene (ppm) in cigarette smoke at a distance of 2,0 meters, 4,0 meters and 10,0 meters from the lit cigarettes.

\begin{tabular}{|l|c|c|c|c|c|c|c|c|c|}
\hline \multirow{2}{*}{$\begin{array}{c}\text { Distance } \\
\text { (meters) }\end{array}$} & \multicolumn{9}{|c|}{ Time of experiment (minute) } \\
\cline { 2 - 10 } & 2,0 & 6,0 & 10,0 & 2,0 & 6,0 & 10,0 & 2,0 & 6,0 & 10,0 \\
\hline 2,0 & $78,2 \pm 6,1$ & $104,5 \pm 8,4$ & $170,4 \pm 8,8$ & $2,9 \pm 0,9$ & $3,8 \pm 0,9$ & 0 & $2,2 \pm 0,2$ & $2,1 \pm 0,2$ & $3,1 \pm 0,8$ \\
\hline 4,0 & $40,1 \pm 2,4$ & $30,3 \pm 2,1$ & $20,9 \pm 1,6$ & $2,6 \pm 0,3$ & $1,8 \pm 0,9$ & 0 & $2,6 \pm 0,3$ & $2,0 \pm 0,4$ & 0 \\
\hline 10,0 & $10,6 \pm 1,8$ & $10,2 \pm 1,1$ & $6,9 \pm 1,0$ & $1,6 \pm 0,1$ & 0 & 0 & 0 & 0 & 0 \\
\hline
\end{tabular}



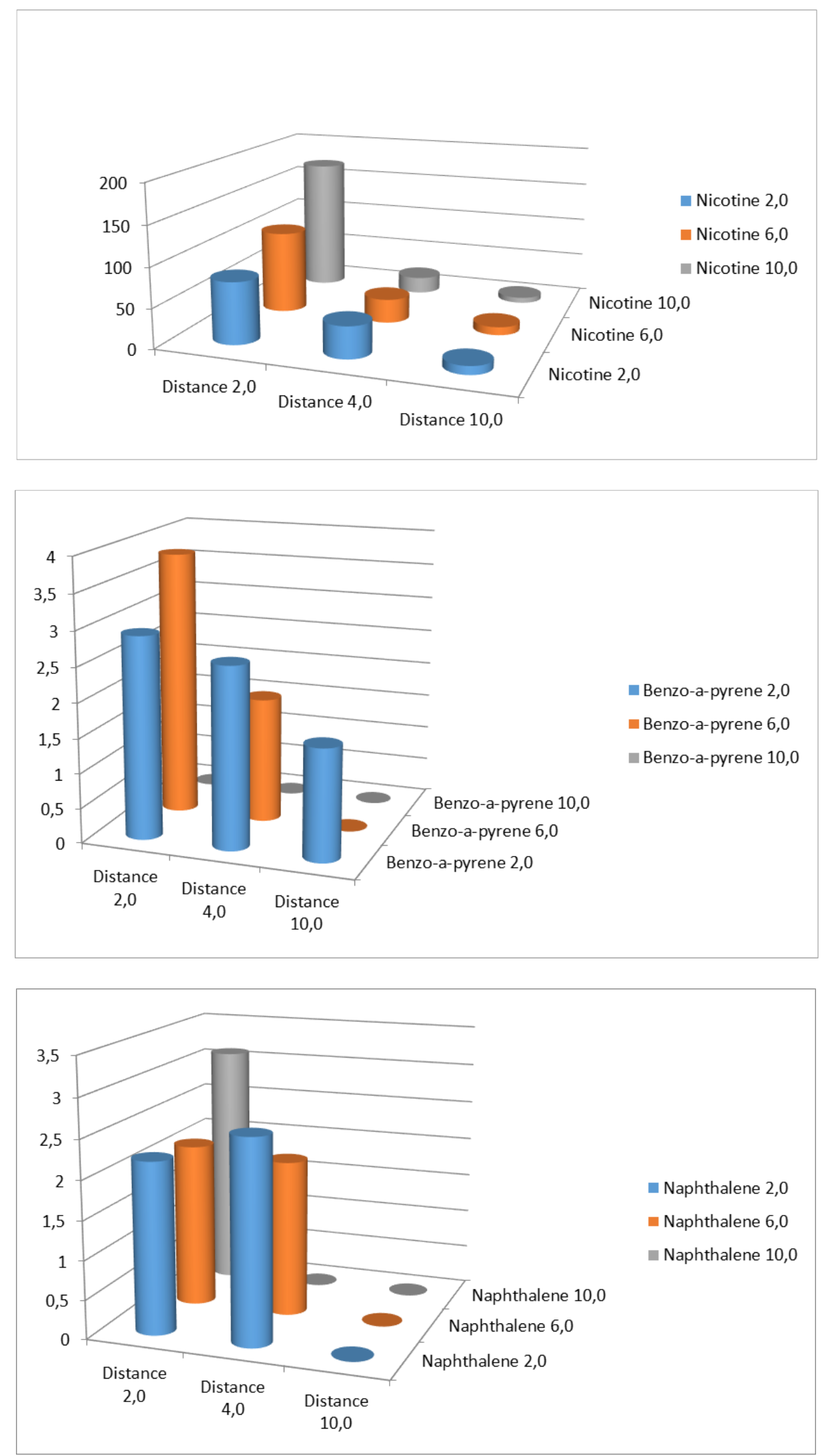

According to the data obtained, the migration intensity of nicotine, benzo-a-pyrene and naphthalene is heterogeneous. The Nicotine concentration in tobacco smoke in closed space under conditions of increasing distance does not exceed 78,2 $\pm 6,1 \mathrm{ppm} \mathrm{2,0} \mathrm{minutes} \mathrm{after} \mathrm{the} \mathrm{start} \mathrm{of} \mathrm{the}$ experiment. And after 4,0 minutes is much lower $-40,1 \pm 2,4 \mathrm{ppm}$. Statistically the difference is 
unmistakable $(\mathrm{P}<0.001)$. Under conditions of increasing distance $(10,0 \mathrm{~m}$ from the source of contamination) the nicotine content in tobacco smoke is further reduced $(10,6 \pm 1,8, \mathrm{ppm}, \mathrm{P}<0,001) .6,0$ minutes after the start of the experiment, the concentration of nicotine in tobacco smoke also decreases with distance. At a distance of 2.0 meters it is equal to $104,5 \pm 8,4$ ppm. $30,3 \pm 2,1 \mathrm{ppm}$ at 4,0 meters. The difference is statistically unmistakable $(\mathrm{P}<0,001)$, and at a distance of $10,0 \mathrm{~m}$ from the source of contamination does not exceed 10,2 $\pm 1,1 \mathrm{ppm}$. The difference is unmistakable $(\mathrm{P}<0,001) .10,0$ minutes after the start of the experiment, the amount of nicotine in the tobacco smoke was $170,4 \pm 8,8 \mathrm{ppm}$ (distance 2,0 m). At a distance of 4,0 m, the nicotine concentration in tobacco smoke does not exceed $20,9 \pm 1,6 \mathrm{ppm}$. Statistically the difference is unmistakable $(\mathrm{P}<0,001) .10,0$ minutes after the start of the experiment, at a distance of $10,0 \mathrm{~m}$, the concentration of nicotine in tobacco smoke was further reduced $(6,9 \pm 1,0 \mathrm{ppm})$. The decrease is statistically unmistakable $(\mathrm{P}<0,001)$.

Evaluation of nicotine concentration of tobacco smoke according to time gives the following picture. 2,0 meters from the source of contamination 2,0 minutes after the start of the experiment $78,2 \pm 6,1 \mathrm{ppm}, 6.0$ minutes after the start of the experiment 104,5 $\pm 8,4 \mathrm{ppm}$. At the same distance, 10,0 minutes after the start of the experiment $-170,4 \pm 8,8 \mathrm{ppm}$. The increase in nicotine content over time was unmistakable $(\mathrm{P}<0,001)$. The air sample at a distance of $4,0 \mathrm{~m}$ after the start of the experiment for $2.0 \mathrm{~min}$ is equal to $40,1 \pm 2,4 \mathrm{ppm}$; And at the same distance 6.0 minutes after the start of the experiment, it did not exceed $30,3 \pm 2,1 \mathrm{ppm}$. The difference is unmistakable $(\mathrm{P}<0,001)$. The concentration of nicotine in tobacco smoke decreases again within 10.0 meters of contamination. It was $10,6 \pm 1,8 \mathrm{ppm}$ at 2.0 minutes after the start of the experiment, $10.2 \pm 1.1(\mathrm{P}>0.05)$ at 6.0 minutes after the same distance, and $6.4 \pm 1.0 \mathrm{ppm}$ after 10.0 minutes. The difference is unmistakable $(\mathrm{P}<0.001)$.

According to the table below, the level of benzo-a-pyrene in tobacco smoke 2,0 minutes after the start of the tobacco experiment is $2,9 \pm 0,3 \mathrm{ppm}$ at a distance of 2,0 meters from the source, and does not exceed 2,6 $60,3 \mathrm{ppm}$ at a distance of 4,0 meters. Statistically, the difference is not proven $(\mathrm{P}>0,05)$. The concentration of benzo-a-pyrene at the indicated time of $10.0 \mathrm{~m}$ is much lower $(1,6 \pm 0,1 \mathrm{ppm}, \mathrm{P}<0,001) .6,0$ minutes after the start of the experiment, the concentration of benzo-apyrene in tobacco smoke at a distance of $2,0 \mathrm{~m}$ from the contamination does not exceed $3,8 \pm 0,3=9 \mathrm{ppm}$ and at a distance of $4,0 \mathrm{~m}$ does not exceed $1,8 \pm 0,9$. Statistically the difference is unmistakable $(\mathrm{P}<0.001)$. At a distance of 10,0 m, 6,0 min after the start of the experiment, it did not exceed the residual values and was therefore not evaluated by us. Benzo-a-pyrene levels in tobacco smoke 10.0 minutes after the start of the experiment did not exceed the residual values at $2.0 \mathrm{~m}, 4.0 \mathrm{~m}$ and $10.0 \mathrm{~m}$ from the contaminated source, respectively.

Estimation of the concentration of benz-a-pyrene in tobacco smoke over time gives the following picture, 2,0 meters from the source of contamination 2,0 minutes after the start of the experiment does not exceed 2,9 $\pm 0,3 \mathrm{ppm}$. 6,0 minutes after the start of the experiment it was significantly increased. $(3,8 \pm 0,9 \mathrm{pp}, \mathrm{P}<0,001)$. And at the same distance the residual values do not exceed after 10,0 minutes. At a distance of 4,0 $\mathrm{m}$ from the source of contamination, the concentration of benz-a-pyrene in tobacco smoke is $2,6 \pm 0,3 \mathrm{ppm}$ and decreases to some extent after 6,0 minutes $(1,8 \pm 0,9 \mathrm{ppm}, \mathrm{P}<, .001)$. After 10.0 minutes it does not exceed the residual values. The tobacco smoke sample at a distance of $10,0 \mathrm{~m}, 2,0$ minutes after the start of the experiment, does not exceed $1,6 \pm 0,1 \mathrm{ppm} .6,0$ and 10,0 minutes after the start of the experiment, it is equal to the residual values.

10.0 minutes after the start of the experiment, the level of benz-a-pyrene of lit cigarettes does not exceed the residual values of 2,0 meters, 4,0 meters and 10,0 meters. Based on the data, 2,0 meters from the destination source, the naphthalene level in tobacco smoke is practically homogeneous $(2,2 \pm 0,2 \mathrm{ppm}$ and $2,1 \pm 0,2 \mathrm{ppm}, \mathrm{P}>0,05)$ after 2,0 and 6,0 minutes from the start of the experiment. Statistically infallible increase in naphthalene $(3,1 \pm 0,8 \mathrm{ppm}, \mathrm{P}<0,01)$ was observed in tobacco samples 10.0 minutes after the start of the experiment. At a distance of 4,0 meters from the source of pollution, the level of naphthalene in tobacco smoke is only slightly lower than the two-meter distance data $(2,0 \pm 0,4 \mathrm{ppm}, \mathrm{P}>0,05)$, And 6,0 and 10,0 minutes after the start of the experiment, the naphthalene content did not exceed the residual values.

In the assessment of rate dynamics, the metabolic processes and photochemical transformations of each component, which can qualitatively and quantitatively alter the composition of tobacco smoke at different distances from the lit cigarette, should be taken into consideration. 
Conclusions. The paper allows us to assess the degree of cleanliness of the surrounding atmosphere in practically closed air space (gym, training rooms, auxiliary rooms, etc.), to determine the nature of the risk experienced by each "passive smoker". The importance of research increases given that children, young people, adolescents, the elderly, and others are often included into the ranks of "passive smokers."

\section{REFERENCES}

1. Геленава Н.Г Табачный дым и его пиролиз. 2009; 3-35. Тбилиси

2. Всемирная Организация Здравоохранения. Доклад ВОЗ о глобальной табачной эпидемии. Создание среды свободной от табака. 2013; 1-24. Москва

3. Зурабашвили Д.З.; Парулава Г.К. Уровень содержания нафталина и его производных в табачном дыме. Мед. Новости Грузии. 2016; 1(250):93-96

4. Зурабашвили Д.3.; Парулава Г.К. Уровень бенз(а)пирена в табачном дыме. Мед. Новости Грузии. 2016; 5(254):107-112

5. Зурабашвили Д.З.; Парулава Г.К. Пассивный курильщик. 2019; 14-29. Москва

6. Cheng K., Okechuku C., Millen B. Association Between Clean Indoor Air Laws and Voluntary Smoke Free Rules in Homes and Cars. Tob. Control. 2015; 168-174 